\title{
MEDICINAL PLANT USE BY SUNDANESE ETHNIC IN NYANGKEWOK HAMLET, SUKABUMI REGENCY
}

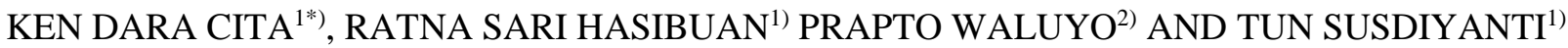 \\ ${ }^{1)}$ Faculty of Forestry, University of Nusa Bangsa, Bogor, Indonesia, 16166 \\ 2) Faculty of Social Science and Culture, University of Pakuan, Bogor, Indonesia 16129 \\ *Email: kendarac@gmail.com
}

Accepted 01 July 2020/Approved 06 September 2020

\begin{abstract}
Sundanese ethnic in Nyangkewok hamlet, Sukabumi has been using medicinal plants to cure and prevent illness. This research aims to identify and describe medicinal plant use by Sundanese Ethnic with indigenous knowledge in Nyangkewok Hamlet, Sukabumi. This research was conducted from February to May 2020 with qualitative method. The research resulted in 103 species of 42 plant families used by the Sundanese community in Nyangkewok Hamlet with Zingiberaceae dominant family, the most used part of the medicinal plants was leaves.
\end{abstract}

Key word: indigenous knowledge, medicinal plants, Sundanese ethnic

\section{INTRODUCTION}

Medication with medicinal plants becomes an alternative to improve society's health and well-being (Moteetee et al., 2018) due to limited access in getting modern medical. Traditional medicine pattern by using medicinal plant has been implemented since long time ago by the local community, especially near forests (Zuhud 2009 b). Traditional medicine has become part of the ethnics' culture in Indonesia, so most ethnics in Indonesia depend so much on medicinal use for their survival (Windadri et al., 2006; Hikmat et al., 2011).

On the international level, the World Health Organization (WHO) shows the concern on traditional medicine development by publishing guidelines regarding good practice as well as research and development in traditional medicine.

Several research results state that traditional medicine with medicinal plants is harmless due to its minimum side effects, and is more affordable, so it can improve society's health, especially rural community and people who live near forests (Royyani dan Rahayu 2010; Rahayu et al. 2006). These results are in line with a study by Kusumawati dan Yogeswara (2016) in which consumption of drug containing things might cause a health complication effect. For that reason, the society agrees that medicinal plant consumption is safer.

More than 2039 medicinal plants are identified to be used by more than 550 ethnics in Indonesia that can cure and treat various diseases (Zuhud 2009a). These lead to a system named indigenous knowledge. Cultural diversity resulted in various kind of medicinal plant use. Ethnobotany information is an essential tool to the development of plant use model that could help indigenous knowledge-based policy planning (Crepaldi et al., 2016), support plant conservation, and improve community's health level, especially the rural community. (Rodríguez et al., 2018; Cita 2020)

Nyangkewok Hamlet is located at Sukabumi Regency on the foot of Mount Gede Pangrango. The community in Nyangkewok Hamlet possesses a traditional knowledge (Cita and Hasibuan 2019) in using medicinal plants. However, the distribution of medicinal plant use applied in Nyangkewok Hamlet is not yet documented. Data and information availability regarding Sundanese Ethnic medicinal plant use in Nyangkewok Hamlet are very limited. For that reason, a research about medical plants use by Sundanese Ethnic community is necessary to get community's traditional knowledge documentation that is starting to decline from an area. It also supports a study by Kandari et al. (2012) stating that a research on society's indigenous knowledge and the interaction with plants can help maintain biodiversity preservation and the development of medicinal plants domestication.

This study aims to identify the form of medicinal plant species use in Nyangkewok Hamlet, and identify the model of medicinal plant use in Nyangkewok Hamlet to maintain indigenous knowledge that can be passed down to and managed by next generation to build health resilience and medicinal plant conservation.

\section{RESEARCH METHOD}

This study was conducted in Nyangkewok Hamlet, Kalaparea Village, Sukabumi Regency on February to May 2020. The map of research location can be seen in Figure 1. The following were tools used in this research: plant exploration tools (compass, GPS, tally sheet, plastic specimen, stationery, and camera), interviewing tools 
(interview guide, recorder), and herbarium making supplies (alcohol, plastic bag, newspaper, paperboard, rope, and label). The objects were medicinal plants and Nyangkewok Hamlet community.

The data were collected using participant observation method, literature study, and interview. The data collection technique was carried out with several steps (Table 1), each data was then analyzed descriptively.

Participatory observation was done by systematically writing down the activities of Nyangkewok Hamlet community where the medicinal plant use was carried out. The researchers involved in some of the informant's activities, especially those that involved medicinal plant use. The collected data included the types of plants, the parts used, and usage method.

The interview was held on 40 respondents out of 2616 heads of family in Nyangkewok Hamlet by using questionnaires and in-depth interview. The respondents were chosen with purposive sampling, where sample members or respondents were chosen specifically. The criteria used here was only those who implemented traditional knowledge and interact with medicinal plant use. The interview was also conducted on the community leader as a key-informant who was considered to have the best comprehension and provide information accurately. The snowball method was applied. It is an informant determination technique based on clues or initial informant determination who are considered able to provide information as needed in research. The three bona fide key informants were selected based on the local community leader's recommendation (Creswell 2016). Herbarium was made to assist the identification of the types of collected medicinal plants. Herbarium was taken to assist the identification of types of collected plants. The plant identification referred to Flora of Java book (Backer and van Den Brink 1968). The data analysis was carried out qualitatively (descriptive) by using the following equation:

1. Respondent characteristics

a. Gender composition

Percentage of sex type

$=\frac{\sum \text { respondent with certain sex type }}{\sum \text { All respondent }} \times 100 \%$

b. Age composition

Percentage of age group

$=\frac{\sum \text { respondent of certain age group }}{\sum \text { All respondent }} \times 100 \%$

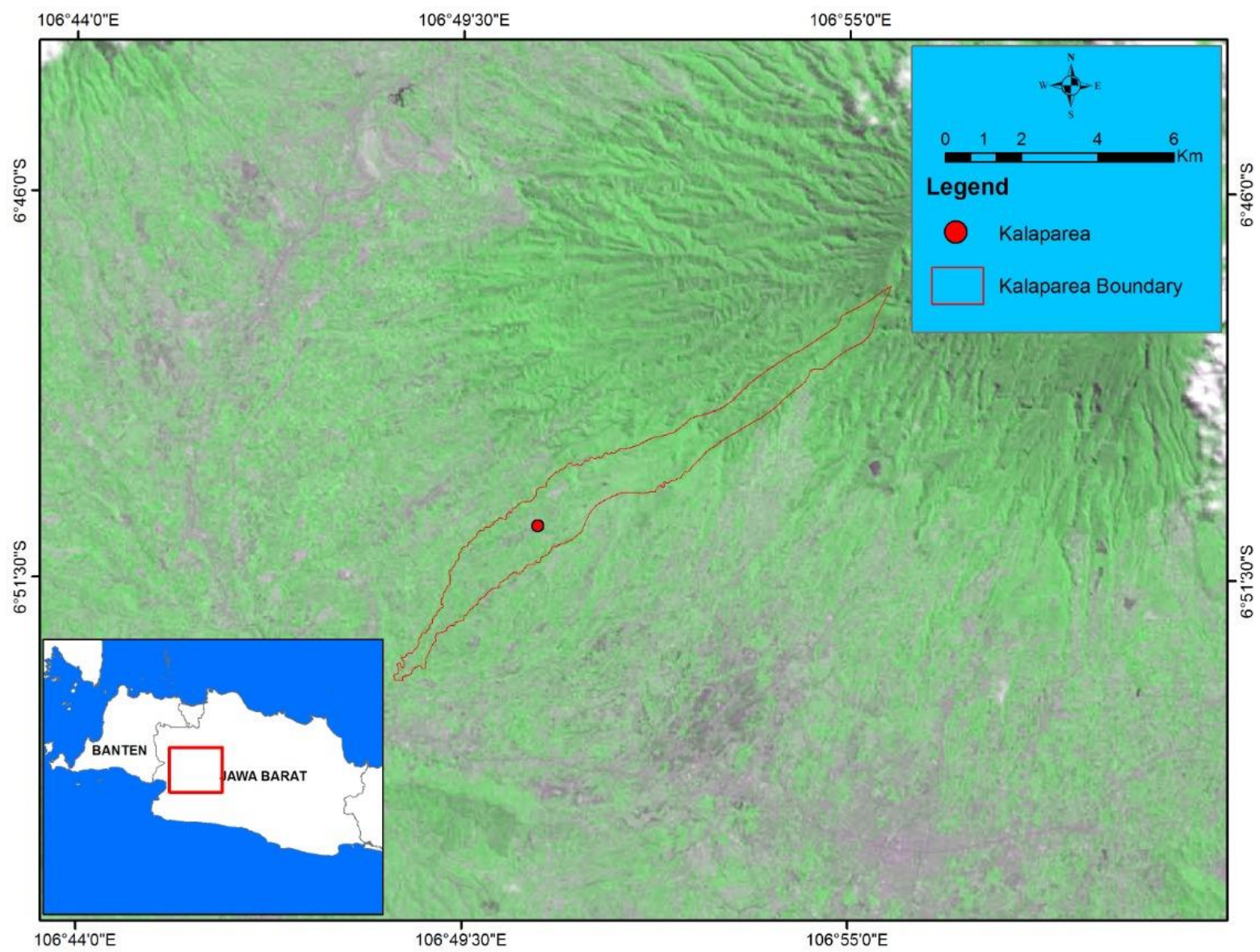

Figure 1. Location map of Nyangkewok Hamlet, Kalaparea Village, Sukabumi Regency. 
2. Plant Use

a. Family percentage $=$ $\frac{\text { Number of species of a family }}{\text { Number of all families }} \times 100 \%$

b. Percentage of parts used $=$ $\frac{\text { Number of specific parts used }}{\text { Number of all parts used }} \times 100 \%$

\section{RESULTS AND DISCUSSION}

\section{Respondent characteristics}

The characteristics of Sundanese Ethnic Community in Nyangkewok Hamlet are that most of them work as farmer and live traditionally. Indigenous knowledge grows within the society, preserved from generation to generation, especially in utilizing plants (Cita and Hasibuan 2019). The total respondents of this research were 40 people, and their age varied from 14 to 80 years old. The description of respondent characteristics in Nyangkewok Hamlet Sundanese Ethnic is represented in Figure 2 and Figure 3.
Figure 2 shows that community's traditional knowledge on medicinal plants in Nyangkewok Hamlet is passed down orally from generation to generation. Respondents with the highest level of knowledge on medicinal plant use to traditionally accommodate health needs were those with Age Group III, i.e., 40-54 years old. At that age, people there were still productive in searching for medicinal plants, both wild and cultivated plants. This is also in accordance with a study (Silva et al., 2011) saying that generally, Age Group III-IV has more detailed indigenous knowledge in medicinal plant use. It does not occur in Age Class $\mathrm{V}$ because nervous mechanisms decrease at very old age, which makes the memory skills weaker as well (Rizio dan Dennis 2014).

Knowledge decrease in young generation is caused by activity change in young age group and the educational system that marginalize ethnobotany indigenous knowledge (Iswandono et al. 2015). A study (Wanjohi et al., 2020) also agrees that old age group has adequate ethnobotany knowledge to become respondents compared to the young generation with less knowledge.

Table 1. Data collection technique

\begin{tabular}{llll}
\hline No & \multicolumn{1}{c}{ Type of data } & \multicolumn{1}{c}{ Studied aspect } & \multicolumn{1}{c}{ Collection method } \\
\hline 1 & $\begin{array}{l}\text { Study of Nyangkewok Hamlet } \\
\text { community general condition }\end{array}$ & $\begin{array}{l}\text { Location and condition of } \\
\text { social community with } \\
\text { Sundanese } \\
\text { characteristics }\end{array}$ & Interview and participatory observation \\
& Study of medicinal plant & Species, family, part used & $\begin{array}{l}\text { Literature review, interview, and } \\
\text { participatory observation }\end{array}$ \\
\hline
\end{tabular}

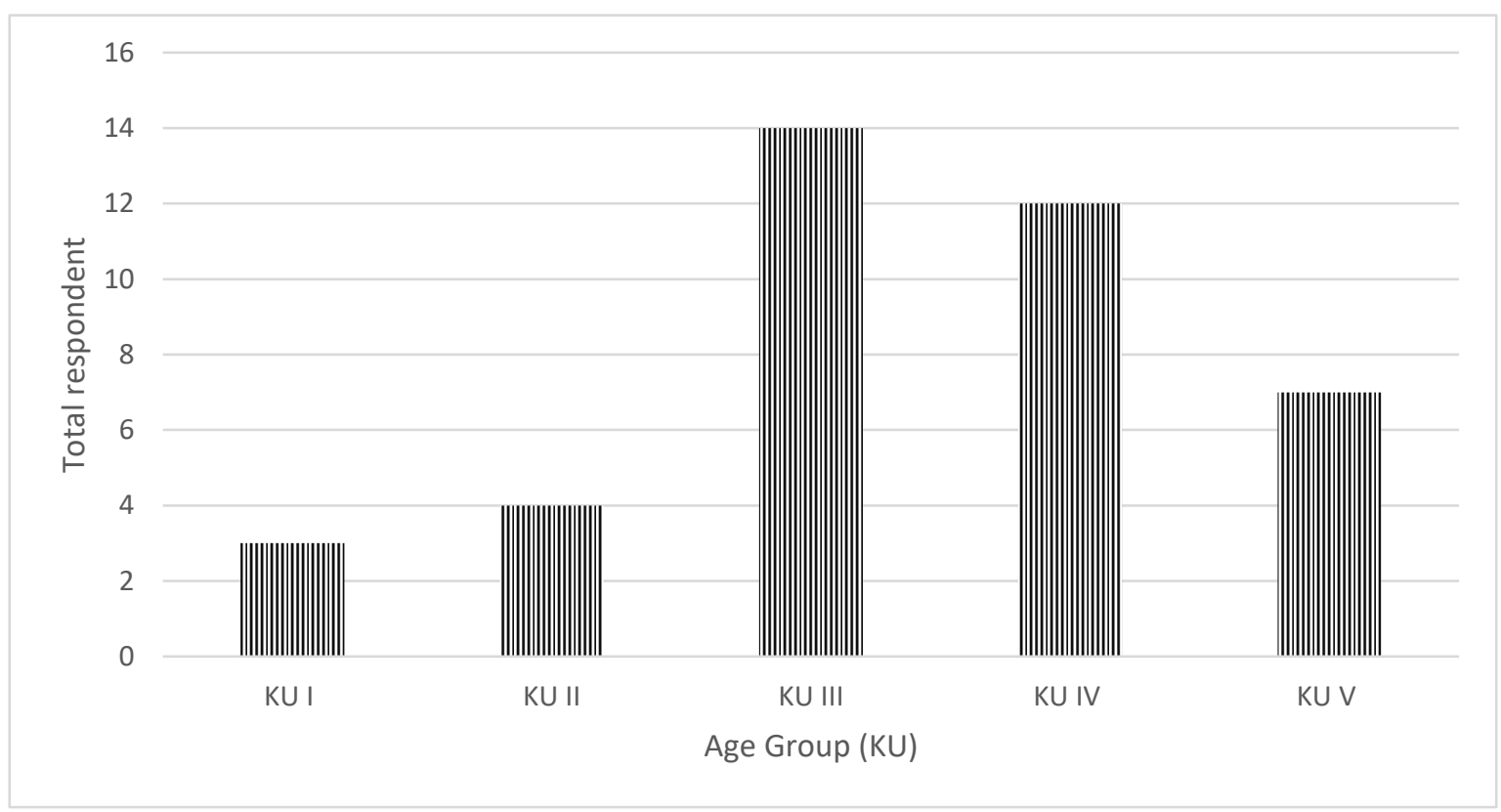

Figure 2 Age group characteristic in Nyangkewok Hamlet 
25

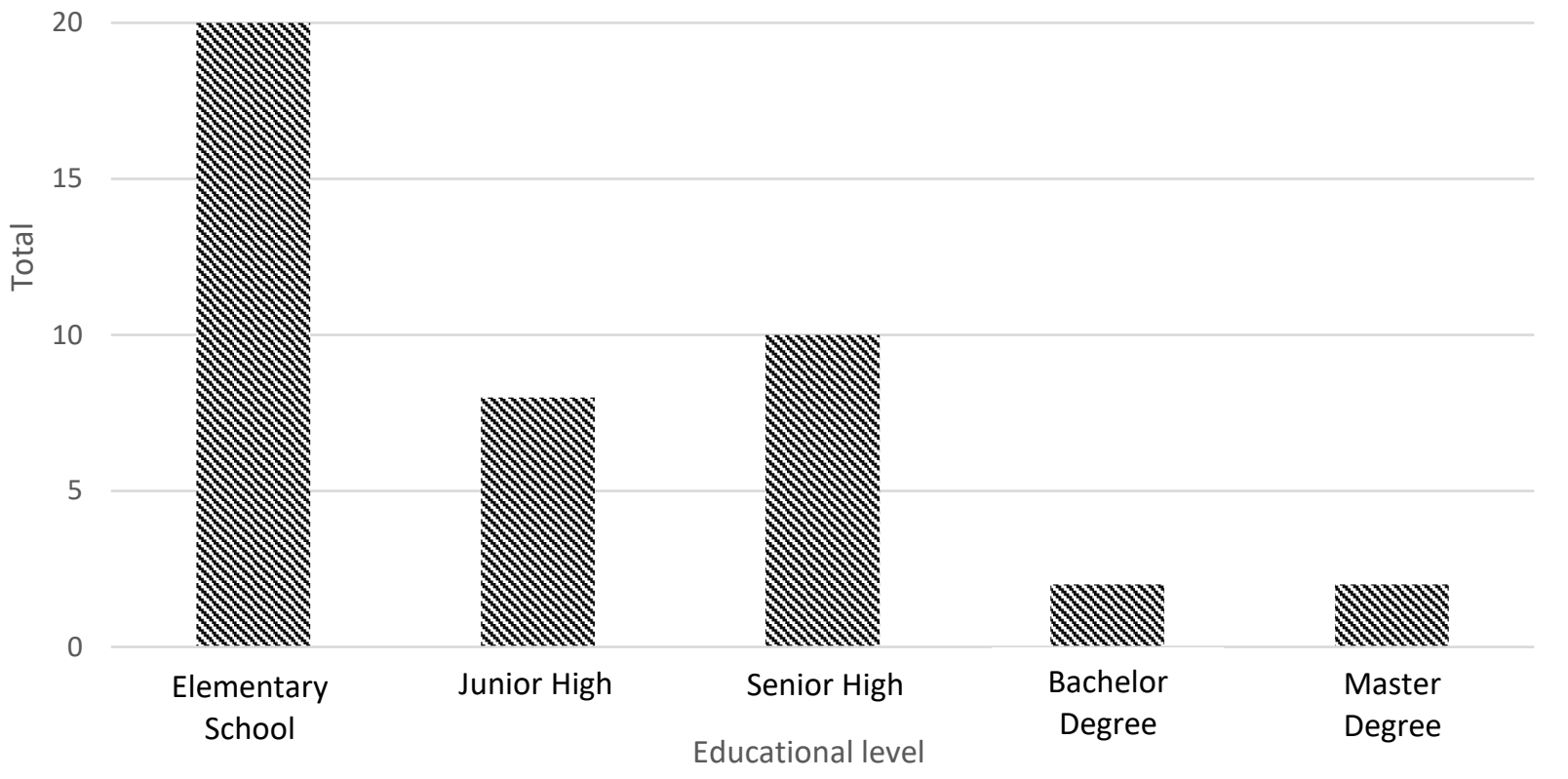

Figure 3 Respondents' educational level in Nyangkewok Hamlet

Young generation looks for more practical and quick treatment by visiting public health center, the reason why knowledge of medicinal plants to cure illness only limited to the old generation. Research (Suryana et al. 2018) in Subang, West Java, and (Wiryono et al. 2020) in Semende Ethnic, Kaur, Bengkulu state that indigenous knowledge has decreased in young generation, so as a global trend it can be said that plant indigenous knowledge among youngsters has been eroded (Aswani et al., 2018)

The educational level of people in Nyangkewok Hamlet was dominated by the Elementary School category. Based on that fact, ethnobotany knowledge level was in fact higher among the people with low formal education background and those who performed most activities in garden, field, etc. This meant that the average educational level that dominated Nyangkewok Hamlet was considered low. A research by Bruyere et al. (2016) in Kenya that compares the traditional knowledge between ranchmen who spend time in nature and their scholar peers states that students with formal education have lower traditional knowledge. It indicates that traditional knowledge needs to be integrated and runs as a curriculum in formal education.

The characteristics research of 40 respondents was dominated by $55 \%$ women and $45 \%$ men. Women hold a more crucial role because they tend to dominate in taking care of ill family members. Women will look for medicine or cultivated medicinal plants in yard. Torres-Avilez et al. (2016) conduct a review research and meta-analysis about gender influence on medicinal plant knowledge. Three types of meta-analysis are applied to different scales in this research. There is no significant difference between men and women However, women have social role that classifies as wife and daughter who are responsible for health, diagnose diseases, so they tend to interact with medicinal plants strongly. Men, on the other hand, are responsible with household economy and provide sources, which direct men to have more knowledge of natural sources for different needs, such as construction.

\section{Medicinal Plant}

\section{a. Medicinal plant type and category}

Research results show 103 types of medicinal plants from 42 families (Figure 4) used by Nyangkewok Hamlet community in accommodating their medicine needs under the status of unprotected conservation according to P.20/MENLHK/SETJEN/KUM.1/6/2018.

The most used medicinal plant species was Zingiberaceae family by $31 \%$ because it could warm bodies, suitable for Nyangkewok Hamlet with low temperature. Many types of Zingiberaceae can be utilized because it cultivates easily and has medicinal properties since the days of our ancestors. The benefits of Zingiberaceae are as spices, seasoning, or ingredients in nutritious remedies with warming effect. The types of it include turmeric (Curcuma domestica), ginger (Zingiber officinale), and aromatic ginger (Kaempferia galanga). A research in Batak Ethnic also shows that Zingiberaceae family is the most used medicinal plant by around 30-40\% (Silalahi et al., 2015; Nasution et al., 2020). Ginger can cure trapped wind, nausea, headache, rheumatic, joint pain, stomachache, cholera, antidote for snake venom, 
sprain, and swelling because it has carminative properties that can release the trapped wind and can also work as a stimulant, stochastic to increase appetite, and diaphoretic to promote healthy sweating (Mulyani et al. 2016). According to Trade Assessment and Development Agency of the Ministry of Trade of the Republic of Indonesia (2017), ginger consumption continues to increase each year. Ginger consumption was 155.949 tons in 2011 and increased to 282.025 tons in 2015 .

Plant species that used as traditional medicine has medicinal properties on one, some, or all parts of its body. Some species have different properties on its body parts within an individual plant. The classification of part of plants used as treatment can be categorized into root, stem, bark, gum, leaf, flower, seed, fruit, peel, rhizome, tuber, tuber skin, all parts (Table 2).

The part of plant used most by Nyangkewok Hamlet community was leaf (52.02\%), while the parts with lowest use rate were gum, peel, and flower that did not even reach
$1 \%$. The results are in accordance with a study by Susanti et al. (2018) about medicinal plant diversity in Lampung Province, which proves leaf as the most part used as medicinal plant by $46 \%$. Additionally (Zuhud 2009b), it also shows that leaf is the medicinal plant potential that is mostly used in tropical forests in Indonesia with a total of 749 species $(33.50 \%)$. Leaf is much used because it is relatively accessible and easy to process by boiling then drink it. According to Hamzari (2008), leaf is the most accessible part, easy to process and mixed compared to the other parts. Leaf is also the part that contains medicinal property substance because it is where photosynthesis takes place. Besides, leaf is easier to concoct and picking leaves will not damage the plant because it has high regeneration rate to grow bud. It also will not significantly affect the growth. Leaf also has general use to treat outer body diseases or wounds on external organs, such as tinea versicolor.

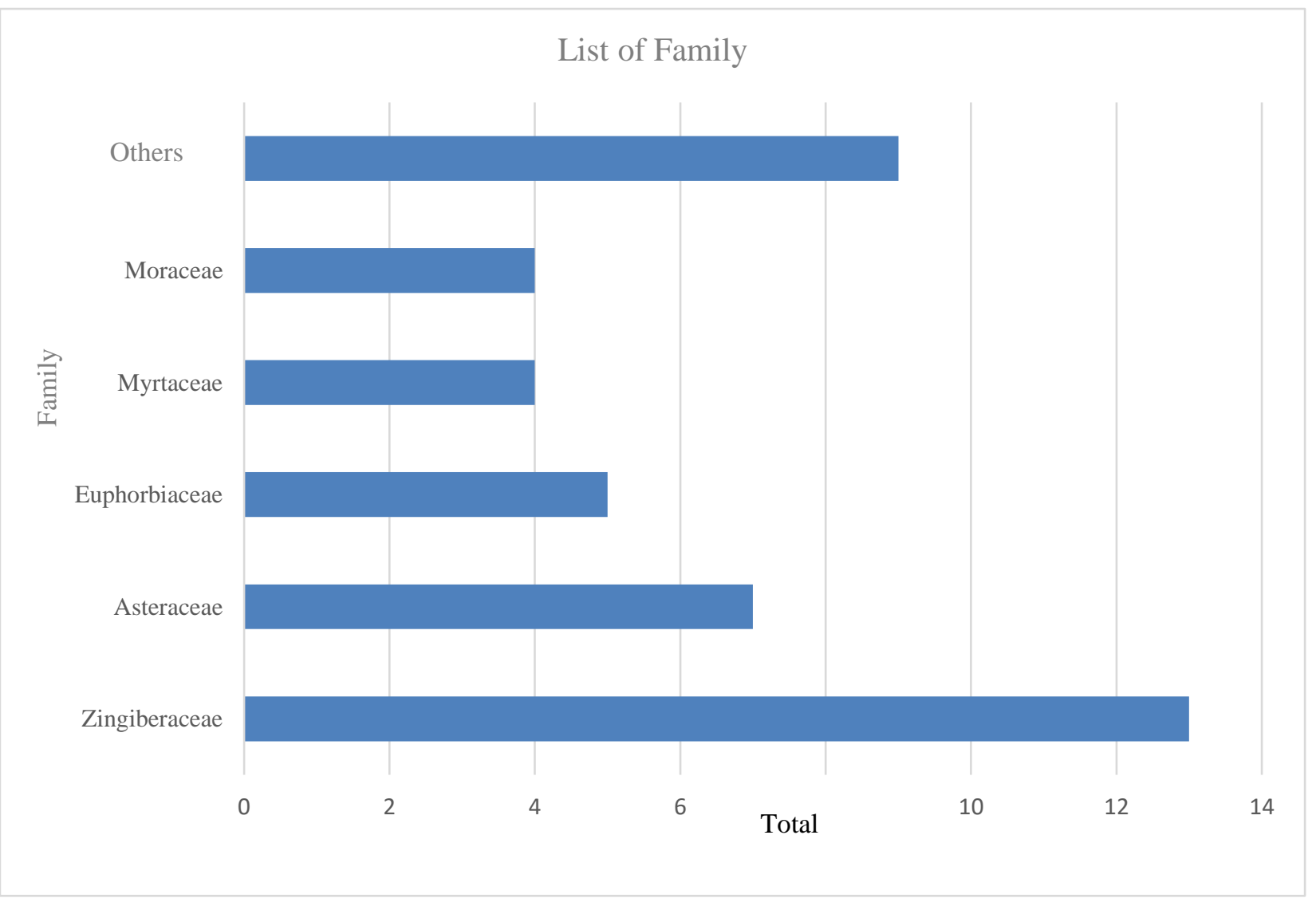

Figure 4 List of medicinal plant families 
Table 2 Used part

\begin{tabular}{llc}
\hline No & Used part & Percentage $(\%)$ \\
\hline 1 & Leaf & 52.02 \\
2 & Rhizome & 16.78 \\
3 & Fruit & 11.09 \\
4 & Herb & 5.29 \\
5 & Stem & 4.81 \\
6 & Root & 2.79 \\
7 & Seed & 2.22 \\
8 & Tuber & 1.95 \\
9 & Tuber skin & 1.76 \\
10 & Gum & 0.55 \\
11 & Peel & 0.43 \\
12 & Flower & 0.31 \\
\hline
\end{tabular}

\section{b. Medicinal plant use method}

The research results show that Nyangkewok Hamlet community was included in society group that used medicinal plants for traditional medicine in a family scale of which lived in rural area.

Medicinal plants have long been a primary need in nature, which makes the relationship of human with botanical development and medicinal plant knowledge inseparable (Shan-an and Zhong-ming 1991). Herbal remedies (jamu) is one of the medicinal plant utilization, the concoction was passed from generation to generation by the ancestors to solve health problems, especially for those who live far from hospital or drugstore (Hidayat et al. 2010). Nyangkewok Hamlet has health facilities and infrastructures, but it is limited in quantity. The health facilities and infrastructures in research location are public health center in subdistrict, integrated healthcare center, nurse, and midwife. This group commonly has low economic condition, so traditional medicine becomes an alternative regarding health needs. Several ways of Nyangkewok Hamlet community in processing and using the medicinal plants are by boiling, shredding then boiling it, and next is squeezing, rubbing, shredding, squeezing, and without processing (Table 3).

The medicinal plant process that was mostly practiced by Nyangkewok Hamlet community was by boiling it with percentage of $73.1 \%$. It is considered the efficient and easiest way to carry out. Boiling is mostly practiced because that way the plant will get cooked, it is safe to consume, and the bitter taste is reduced when compared to direct consumption. Medicinal plant species that often boiled by the community were as follow: red betel ( $P$. crocatum), cat' whiskers plant (O. aristatus), and katuk ( $S$. androgynus). Other way performed by Nyangkewok Hamlet community was shredding and boiling by $10.9 \%$, the medicinal plants used were ginger
(Z. officinale), turmeric (C. longa), galangal (A. galanga), curcuma ( $C$. zanthorrhiza) and aromatic ginger $(K$. galanga). Boiling is the common method used in processing medicinal plants. According to Kinho et al. (2011), boiling might bring the medicinal property substance entirely out from the plant or reduce the unwanted poison. Some medicinal plants are not processed at all, such as guava ( $P$. guajava) and coconut (Cocos nucifera). This is in line with a study by Ramadhani et al. (2020) in West Java among Cintakarya Village community where they use gedi leaf (Abelmoschus manihot) and cape jasmine (Gardenia augusta) to cure fever by boiling it. The boiling technique should not use iron, aluminum, or brass pot because those materials might create sediment, low concentrated medicine solution, cause poisoning, or side effects due to the chemical reaction with the medicinal substances. In addition, boiling technique must use clear and plain water except other provisions are required. To solve fever and influenza, boiling is carried out with great flame technique, and it must be boiled quickly to prevent excessing evaporation of active component substances (Kinho et al. 2010). Community and ethnics in Indonesia have certain experiences and beliefs that influence their knowledge in medicinal plant use. Local community since long ago could solve health issues with medicines they got from natural products. This proves that medicines that come from natural products, especially medicinal plants, have an important role in improving community's health.

\section{Illness}

Based on the interview results, ill in Sundanese language is "gering" or "teu damang". Nyangkewok Hamlet community divides illness into minor illness or "panyawat nu henteu abot" in Sundanese language, and serious illness or "panyawat nu abot". The community can identify the 
illness and treat it with medicinal plants based on the experiences of the ancestor hereditary. The following are five disease groups the Nyangkewok Hamlet community most suffer from (Table 4).

The common diseases Nyangkewok Hamlet community suffer from were ulcer, cough, fever, joint pain, and rheumatic. Those diseases are mostly suffered by the community in rural area in West Java due to the low temperature with high humidity level, causing them to be easily infected by virus (Maryani et al. 2004). What caused the diseases are age factor, lack of nutritional intake in food (beans, green vegetables), and most people in rural area work as farmers that make them do heavy duties like plowing, consequently they often complain about joint pain especially on feet and knee. The same thing happened in another rural area of West Java, i.e., Cintakarya Village, Pangandaran (Ramadhani et al. 2020), in which the lasting and heredity disease among the community are cold, cough, joint pain, and gastritis. Cold and cough can be cured with lime (Citrus aurantifolia) and cardamom (Amomum compactum). Rheumatic and joint pain will be treated with the boiling the soursop leaf (Annona muricate) and leaves of drumstick tree (Moringa oleifera).

Moreover, the Nyangkewok Hamlet community also use medicinal plants around the houses to treat ulcer, for example they will use betel leaf (Piper betle) boiled water as antibiotic (Figure 6).

Table 3 Medicinal plant processing method

\begin{tabular}{llc}
\hline No & Processing Method & Percentage $(\%)$ \\
\hline 1 & Boil & 73.1 \\
2 & Shred, boil & 10.9 \\
3 & Shred, squeeze & 4.1 \\
4 & Squeeze & 1.9 \\
5 & Rub & 0.9 \\
6 & Squeeze & 1.8 \\
7 & Without any processing & 7.3 \\
\hline
\end{tabular}

Table 4 Disease group the community suffer from

\begin{tabular}{rlcc}
\hline No & Illness group & Number of species & Percentage \\
\hline 1 & Fever, cold, ulcer, influenza & 42 & $30 \%$ \\
2 & Muscle pain, joint pain, rheumatic & 34 & $24 \%$ \\
3 & Heart disease and blood circulatory disorders & 25 & $18 \%$ \\
4 & Digestive tract & 22 & $16 \%$ \\
5 & Kidney, urinary tract, and liver & 16 & $12 \%$ \\
\hline
\end{tabular}

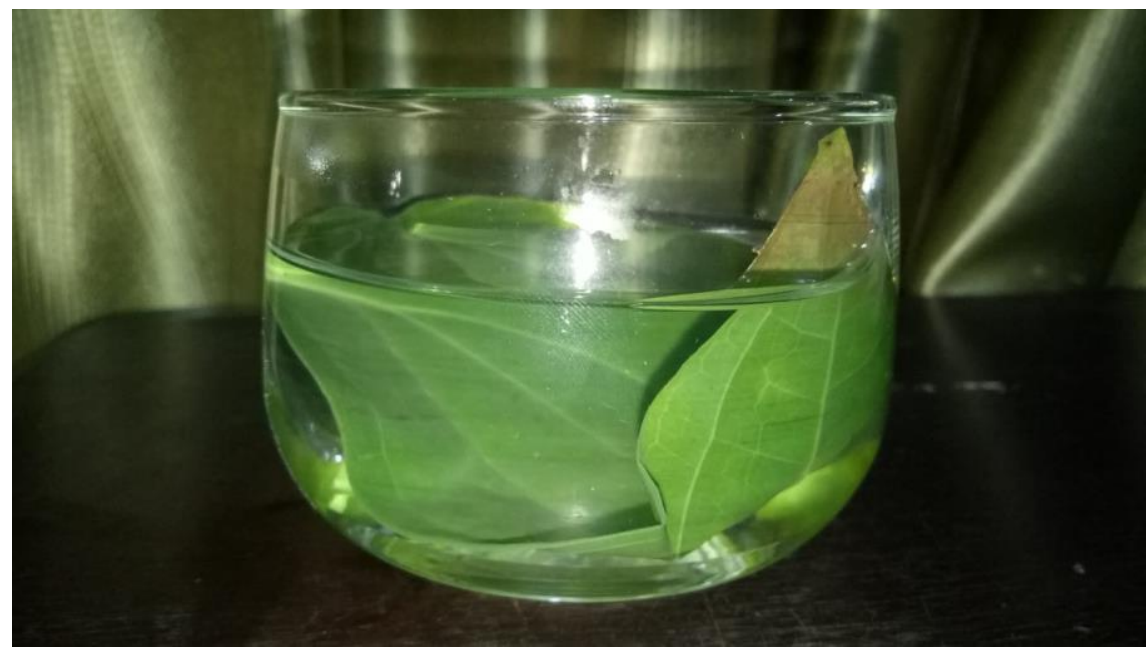

Figure 6 Betel leaf boiled water 


\section{CONCLUSION}

Nyangkewok Hamlet community uses 103 species of medicinal plants that consist of 42 plant families for traditional medicine. The most used medicinal plant species was Zingiberaceae family by $31 \%$, and the most used part of plant was leaf by $52.02 \%$, either by boiling, shredding then boiling, boiling then squeezing, rubbing, shredding, squeezing, or without being processed. The most disease treated with medicinal plant traditional medicine by Nyangkewok Hamlet community were ulcer, cough, fever, joint pain, and rheumatic.

\section{ACKNOWLEDGEMENT}

The researchers would like to express the gratitude to Kemenristek (Ministry of Research and Technology)/BRIN, LLDIKTI IV for the grant funds according to Decree number 10/E1/KPT/2020 and to Nyangkewok Hamlet communities who have helped with data collection.

\section{REFERENCES}

Backer CA, van den Brink RCB. 1965. Flora of Java. Groningen: N. V. P. Noordhoff.

Badan Pengkajian dan Pengembangan Perdagangan Kementerian Perdagangan Republik Indonesia. 2017. Info Komoditi Tanaman Obat. Jakarta: Kementrian Perdagangan.

Aswani S, Lemahieu A, Sauer WHH. 2018. Global trends of local ecological knowledge and future implications. Plos One. 13(4): 1-19.

Batoro J, Setiadi D, Chikmawati T, Purwanto Y. 2013. Pengetahuan tumbuhan Masyarakat Tengger di Bromo Tengger Semeru Jawa Timur. Wacana Journal of Social and Humanity Studies. 14(1): 110 .

Bruyere BL, Trimarco J, Lemungesi S. 2016. A comparison of traditional plant knowledge between students and herders in Northern Kenya. Journal of Ethnobiology and Ethnomedicine. 12(1): 1-10. http://dx.doi.org/10.1186/s13002-016-0121-z.

Cita KD. 2020. Ethnobotany of food plant used by Sundanese Ethnic in Kalaparea Village, Nyangkewok Hamlet, Sukabumi District, Indonesia. Asean Journal of Ethnobiology. 3(1): 1622.

Cita KD, Hasibuan RS. 2019. Utilization of food plant by Sundanese Ethnic, in Nyangkewok Hamlet, Sukabumi Regency. Media Konservasi. 24(3): 303313.

Crepaldi CG, Campos JLA, Albuquerque UP, Sales MF. 2016. Richness and Ethnobotany of the family Euphorbiaceae in a Tropical Semiarid Landscape of Northeastern Brazil. South African Journal of Botany.

102:

157-65. http://dx.doi.org/10.1016/j.sajb.2015.06.010.

Creswell JW. 2016. Research Design: Qualitative, Quantitative, and Mixed Methods Approaches. Yogyakarta: Pelajar.

Hamzari. 2008. Identifikasi tanaman obat-obatan yang dimanfaatkan oleh masyarakat sekitar Hutan TaboTabo. Jurnal Hutan dan Masyarakat. 3(2):111-234.

Hidayat S, Hikmat A, Zuhud EAM. 2010. Ethnobotanical study of local people at Dukuh Cultural Village Garut Regency, West Java. Media Konservasi. 15(3): 139-51.

Hikmat A, Zuhud EAM, Siswoyo, Sandra E, Sari RK. 2011. Revitalisasi Konservasi tumbuhan obat keluarga (Toga) Guna meningkatkan kesehatan dan ekonomi keluarga mandiri di Desa Contoh Lingkar Kampus IPB Darmaga Bogor. Jurnal Ilmu Pertanian Indonesia 16(2): 71-80.

Iswandono E, Zuhud EAM, Hikmat A, Kosmaryandi N. 2015. The ethnobotany knowledge of Manggarai Tribe and the implication utilization of forest plants in The Mountains of Ruteng." Jurnal Ilmu Pertanian Indonesia 20(3): 171-81.

Kandari LS, Phondani PC, Payal KC, Maikhuri RK. 2012. Ethnobotanical study towards conservation of medicinal and aromatic plants in Upper Catchments of Dhauli Ganga in the Central Himalaya. Journal of Mountain Science. 9(2): 286-96.

Kinho J, Arini DID, Halawane J, Nurani L, Halidah, Kafiar Y, Karundeng MC. 2010. Domestikasi Tumbuhan Obat Tradisional di Provinsi Sulawesi Utara. Manado: Balai Penelitian Kehutanan Manado.

Kusumawati IW, Yogeswara IBA. 2016. Antioxidant and bacterial capacity of loloh sembung based on extraction method. Trad. Med Journal. 21(3):14348 .

Moteetee A, Moffett RO, Seleteng-Kose L. 2018. A review of the ethnobotany of the Basotho of Lesotho and The Free State Province of South Africa (South Sotho). South African Journal of Botany. 122:21-56.

Mulyani H, Widyastuti SH, Ekowati VI. 2016. Tumbuhan herbal sebagai jamu pengobatan tradisonal terhadap penyakit dalam serat primbon jampi jawi jilid I. Jurnal Penelitian Humaniora. 21(2):73-91.

Nasution J, Riyanto, Chandra RH. 2020. Kajian etnobotani Zingiberaceae sebagai bahan pengobatan tradisional Etnis Batak Toba Di Sumatera Utara. Media Konservasi. 25(1):98-102.

Rahayu M, Sunarti S, Sulistiarni D, Prawiroatmodjo S. 2006. Pemanfaatan tumbuhan obat secara tradisional oleh masyarakat lokal di Pulau Wawonii, Sulawesi Tenggara. Biodiversitas. 7(3):245-50.

Ramadhani S, Iskandar J, Husodo T. 2020. Studi etnobotani pemanfaatan tumbuhan obat di Desa Cintakarya, Kabupaten Pangandaran, Jawa Barat. Pros Sem Nas Masy Biodiv Indon. 6:500-504.

Rizio AA, Dennis NA. 2014. The cognitive control of memory: Age differences in the neural correlates of 
successful remembering and intentional forgetting. Plos One. 9(1):1-2.

Rodríguez MA, Angueyra A, Cleef AM, Van Andel T. 2018. Ethnobotany of the Sierra Nevada Del CocuyGüicán: Climate change and conservation strategies in the Colombian Andes. Journal of Ethnobiology and Ethnomedicine. 14(1):1-12.

Royyani MF, Rahayu M. 2010. Pengetahuan lokal tumbuhan obat masyarakat Desa Dompo-Dompo Jaya, Pulau Wawonii - Sulawesi Tenggara. Jurnal Teknologi Lingkungan. 11(2):157.

Shan-an H and Zhong-ming C. 1991. The role of Chinese Botanical Gardens in conservation of medicinal plants. Di dalam: Akerele O, Heywood V, Synge H, editor. Conservation in Medicinal Plants. Cambridge: Cambridge University Press.

Silalahi M, Supriatna J, Walujo EB, Nisyawati. 2015. Local knowledge of medicinal plants in Sub-Ethnic Batak Simalungun of North Sumatra, Indonesia. Biodiversitas. 16(1):44-54.

Silva FD, Ramos MA, Hanazaki N, de Albuquerque UP. 2011. Dynamics of traditional knowledge of medicinal plants in a rural community in the Brazilian Semi-Arid Region. Brazilian Journal of Pharmacognosy. 21(3):382-91.

Suryana, Iskandar J, Parikesit, Partasasmita R. 2018. Ethnobotany of Tree ferns in Pasir Menyan Hamlet, Sukamandi Village, Subang, West Java, Indonesia. Biodiversitas. 19(6):2044-2051.

Susanti AD, Wijayanto N, Hikmat A. 2018. Keanekaragaman jenis tumbuhan obat di Agroforestri Repong Damar Krui, Provinsi Lampung. Media Konservasi 23(2):162-68.

Torres-Avilez W, de Medeiros PM, Albuquerque UP. 2016. Effect of gender on the knowledge of medicinal plants: Systematic review and metaanalysis. Evidence-based Complementary and Alternative Medicine. 2016:12-15.

Utami RD, Zuhud EAM, Hikmat A. 2019. Medicinal ethnobotany and potential of medicine plants of Anak Rawa Ethnic at The Penyengat Village Sungai Apit Siak Riau. Media Konservasi. 24(1):40-51.

Wanjohi BK, Sudoi VK, Njenga EW, Kipkore W, 2020. Ecological knowledge of indigenous plants among the Marakwet Community (Embobut Basin), Elgeyo Marakwet County (Kenya). Evidence-based Complementary and Alternative Medicine. 2020(4):1-8

Windadri FI, Rahayu M, Uji T, Rustiami H. 2006. Uses of plants as medicine by Muna People, Sub District Wakarumba, District Muna, Province of North Sulawesi. Biodiversitas. 7(4):333-39.

Wiryono, Wanadi Y, Ilahi AK, Deselina, Senoaji G, Siswayhono. 2020. The local knowledge of the plant names and uses by Semende Tribe People in Kaur District, Bengkulu Province, Indonesia. Biodiversitas. 20(3):754-61.

Zuhud EAM. 2009a. Kebijakan pembangunan kesehatan masyarakat indonesia yang 'Bhineka Tunggal Ika' dengan pengembangan potensi lokal ethno-forestpharmacy (Etno-Wanafarma) pada setiap wilayah sosio-biologi satu-satuan masyarakat kecil. Seminar POKJANASTOI XXXVI; 13 dan 14 Mei 2009; Yogyakarta. Yogyakarta: Universitas Sanata Dharma.

Zuhud EAM. 2009b. Potensi hutan tropika Indonesia sebagai penyangga bahan obat alam untuk kesehatan bangsa. Jurnal Bahan Alam Indonesia. 6(6):227-32. 